\title{
PELATIHAN PEMBUATAN KOMPOS LIMBAH PETERNAKAN PADA KELOMPOK PETANI JAHE MERAH PEMULA DI KEL. BOTING KEC. WARA KOTA PALOPO
}

\author{
Ulfah Zakiyah ${ }^{1 *}$ \\ Rosmalah Yanti² \\ ${ }^{1}$ Agroteknologi Universitas Cokroaminoto Palopo, Palopo, Indonesia \\ 2 Pendidikan Guru Sekolah Dasar, Universitas Cokroaminoto Palopo, Palopo, Indonesia \\ ulfahzakiyah@uncp.ac.id ${ }^{\left.1^{*}\right)}$ \\ rosmalah@uncp.ac.id ${ }^{2)}$
}

Kata Kunci: [Kompos, Jahe Merah, Limbah Peternakan, Fermentasi singkat]

Published by:

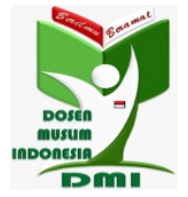

Copyright (C) 2021 The Author(s)

This article is licensed under CC BY 4.0 License

\section{(cc) $\mathrm{BY}$}

https://dmi-journals.org/jai/

\begin{abstract}
Abstrak: Warga Kel. Boting Kec. Wara Kota Palopo yang kegiatannya lebih banyak di rumah (saat pemberlakuan aturan bekerja dari rumah) memanfaatkan lahan pekarangan sebagai areal penanaman jahe merah. Untuk menyuburkan tanaman jahe merah, petani pemula ini menggunakan kotoran ternak ayam yang masih baru. Kegiatan ini diadakan dalam rangka melatih dan mendampingi petani jahe merah pemula dalam mengolah kotoran ternak ayam menjadi kompos dalam waktu singkat. Kegiatan yang diikuti oleh 17 orang ini dilaksanakan dengan metode eksperimen dimana petani pemula mempraktikkan langsung pembuatan kompos berbahan dasar kotoran ternak. Kompos yang dibuat mulai terlihat hasilnya dalam 1 bulan pertama sejak pengaplikasian.
\end{abstract}




\section{Pendahuluan}

Penyebaran virus Corona SARS-CoV-2 (penyebab covid-19) saat ini masih menjadi berita utama di setiap media informasi. Berbagai jenis pengobatan diupayakan untuk menekan jumlah korban covid-19. Minimnya informasi mengenai penanganan virus jenis baru ini, menimbulkan berbagai persepsi mengenai informasi obat terkait. Salah satu gejala dari penyakit ini adalah kesulitan bernafas. Jahe merah merupakan salah satu varietas jahe dengan kandungan senyawa aktif tertinggi jika dibandingkan dengan varietas jahe lainnya. Jahe merah dipercaya oleh masyarakat sebagai salah satu bahan rempah yang dapat menyegarkan sistem pernafasan.

Berdasarkan temuan Assegaf dkk (2020), ekstrak jahe merah (Zingiber officinale var. rubrum) memiliki aktivitas antibakteri terhadap $S$. pyogenes yang merupakan penyebab faringitis. Supu dkk (2018) menyatakan bahwa jahe merah juga memiliki aktivitas antiinflamasi, antidiabetik, antioksidan dan antimietik. Sedangkan Putra (Indonesia Window, 17 Maret 2020) menyatakan bahwa jahe merah berfungsi sebagai antiinflamasi yang mampu meredakan permasalahan pernafasan. Belum ditemukan penelitian yang menyatakan bahwa jahe merah mampu mengobati covid-19.

Jahe merah merupakan salah satu tanaman yang mudah ditemukan di Indonesia. Sebagian besar masyarakat percaya bahwa bahan ini mampu meningkatkan sistem imunitas tubuh. Kalbe Farma menyatakan tingginya permintaan produk herbal cair yang terbuat dari jahe merah sejak merebaknya covid-19 (The Jakarta Post, 12 Maret 2020). Kebutuhan pasar yang sangat tinggi menjadikan budidaya tanaman jahe merah mulai dilirik oleh petani kecil.

Jahe merah menyukai tanah subur, gembur dan memiliki bahan organik yang tinggi. Jahe merah yang dibudidayakan di pekarangan rumah juga memiliki prospek yang menjanjikan. Umumnya, jenis tanah yang tersedia di pekarangan rumah memiliki bahan organik yang rendah. Sehingga, untuk meningkatkan jumlah bahan organik pada tanah jenis ini adalah dengan menambahkan pupuk organik. Beberapa petani pemula yang terlibat dalam kegiatan observasi awal perencanaan kegiatan abdimas, menyatakan akan memakai pupuk kimia untuk menyuburkan tanaman. Ketika ditawari kesediaannya untuk ikut pelatihan pembuatan kompos, beberapa diantaranya menyatakan bahwa pembuatan kompos cukup menyita waktu hingga siap digunakan, sehingga dirasa kurang efektif. Limbah hewan ternak pribadi milik petani jahe merah dinilai potensial untuk dijadikan bahan baku pembuatan kompos.

Kegiatan abdimas kali ini memiliki bertujuan melatih petani jahe merah pemula untuk memanipulasi kondisi pengomposan sehingga dapat memproduksi kompos dalam waktu singkat. Tujuan lainnya yaitu memberi alternatif pupuk yang dapat diusahakan petani pemula untuk mendukung usaha budidayanya. Dengan memberi pelatihan kepada anggota kelompok petani jahe merah pemula di daerah tersebut, diharapkan dapat memberi pengetahuan baru bagi petani mengolah limbah peternakan menjadi lebih bermanfaat.

\section{Metode Pelaksanaan}

Kegiatan ini dilaksanakan di Kelurahan Boting Kecamatan Wara Kota Palopo pada Desember 2020 sebagaimana yang terlihat pada Gambar 1. Mitra kegiatan ini adalah 
peternak ayam kampung sekaligus petani jahe merah pemula yang ada di lokasi yang dimaksud. Kegiatan ini meliputi pemberian pelatihan pembuatan aktivator kompos, perbanyakan aktivator, pengolahan kotoran ternak ayam menjadi kompos, dan pendampingan aplikasi kompos yang telah dibuat pada tanaman jahe merah. Keberhasilan kegiatan ini diukur dari durasi pengomposan dan tingkat pertumbuhan bibit tanaman jahe merah menggunakan kompos yang telah dibuat.

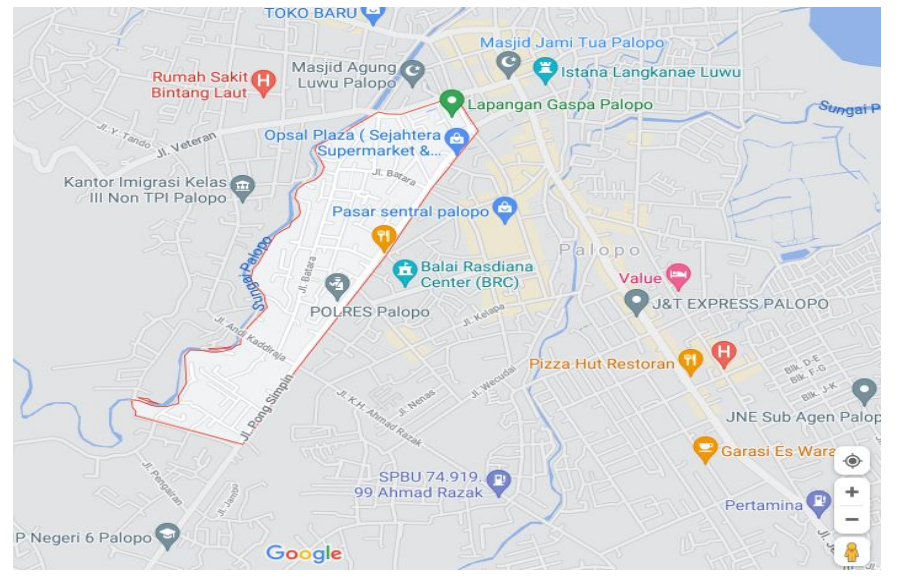

Gambar 1. Peta Kel. Boting, Kec. Wara Kota Palopo

\section{Hasil dan Pembahasan}

Pelaksanaan kegiatan abdimas ini terdiri atas beberapa tahapan. Tahapan pertama adalah pelatihan pembuatan aktivator pupuk dan perbanyakan aktivator. Gambar 2 . menyajikan tahapan perbanyakan aktivator pupuk hingga siap pakai.
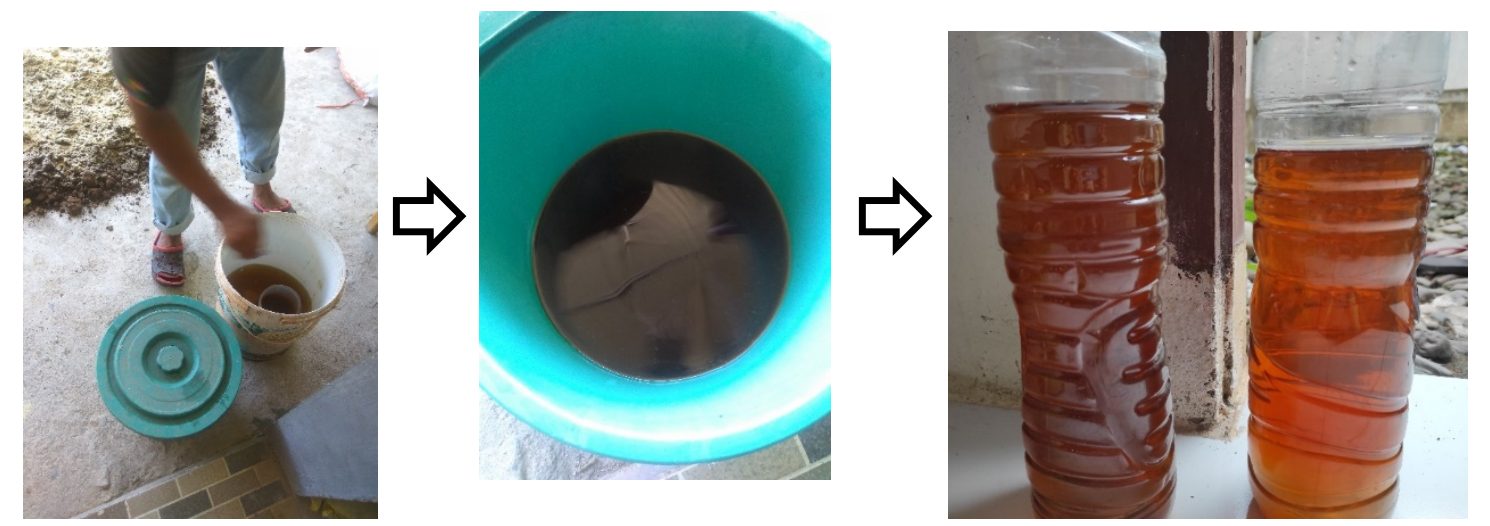

Gambar 2. Pembuatan dan Perbanyakan Aktivator

Beberapa peserta kegiatan mengapresiasi jenis-jenis aktivator yang mudah ditemukan dalam kehidupan sehari-hari serta dapat digunakan dalam pembuatan kompos. Aktivator pupuk yang digunakan pada pelaksanaan kegiatan ini adalah aktivator pupuk yang beredar di pasaran. Pelaksana memilih jenis ini karena mudah diperoleh dan rendemen hasil yang banyak. Aktivator yang digunakan dalam pelatihan ini merupakan campuran jenis aktivator komersial dan jenis aktivator dari buah yang mudah membusuk dan susu basi. Tahapan kedua yaitu pengolahan limbah peternakan menjadi pupuk organik kompos. Bentuk awal limbah peternakan yang dikumpulkan oleh para peserta disajikan pada Gambar 3. 


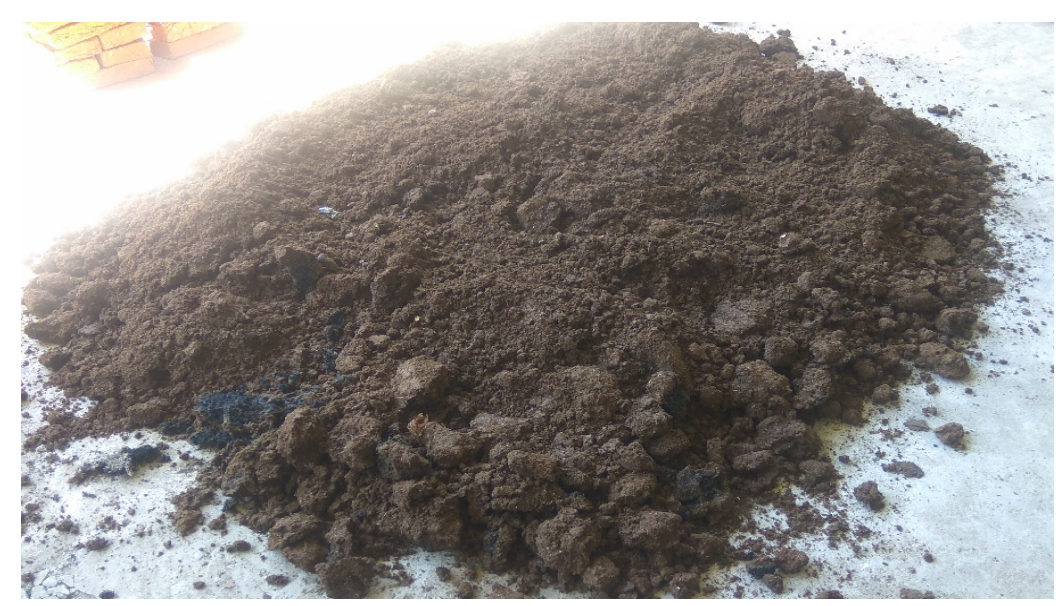

Gambar 3. Bahan dasar kompos

Tahapan pengolahan limbah peternakan menjadi pupuk organik kompos yakni penambahan dedak, penambahan aktivator sebagaimana ditampilkan pada Gambar 4.

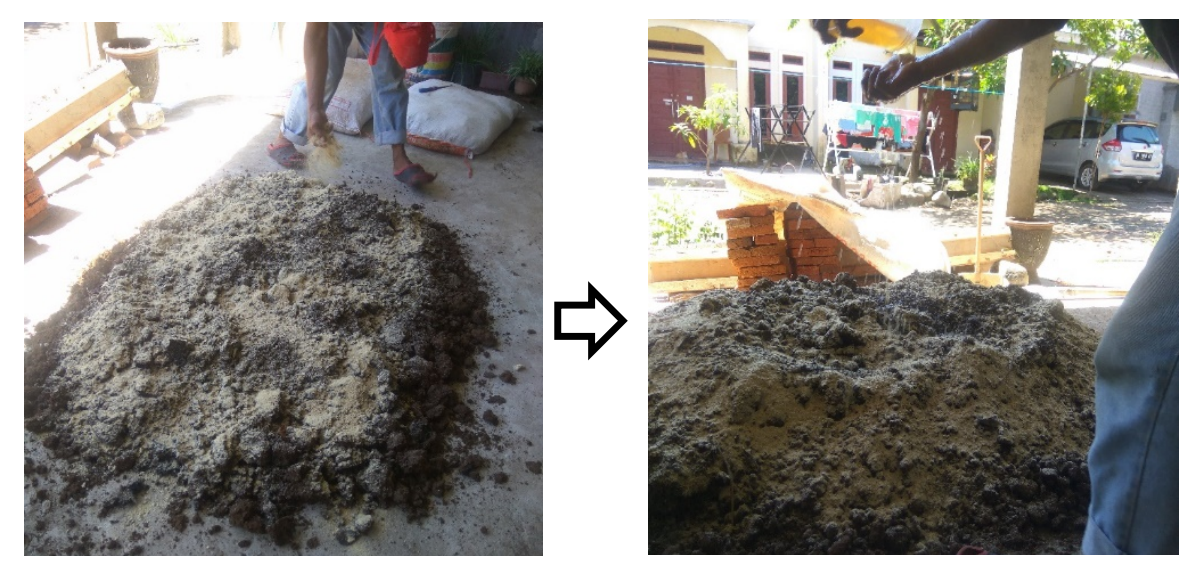

Gambar 4. Penambahan dedak (kiri) dan Penambahan aktivator (kanan)

Proses selanjutnya adalah proses fermentasi pada lantai berpori dan ditutup seperti yang diperlihatkan pada Gambar 5. Dengan menutup bahan baku kompos selama proses fermentasi membantu mempercepat peristiwa pengomposan. Selama proses penutupan ini, dibantu dengan pembalikan bahan baku, dapat menjaga kelembapan campuran dan mempercepat pematangan bahan baku menjadi kompos (Costa, et. al., 2016).

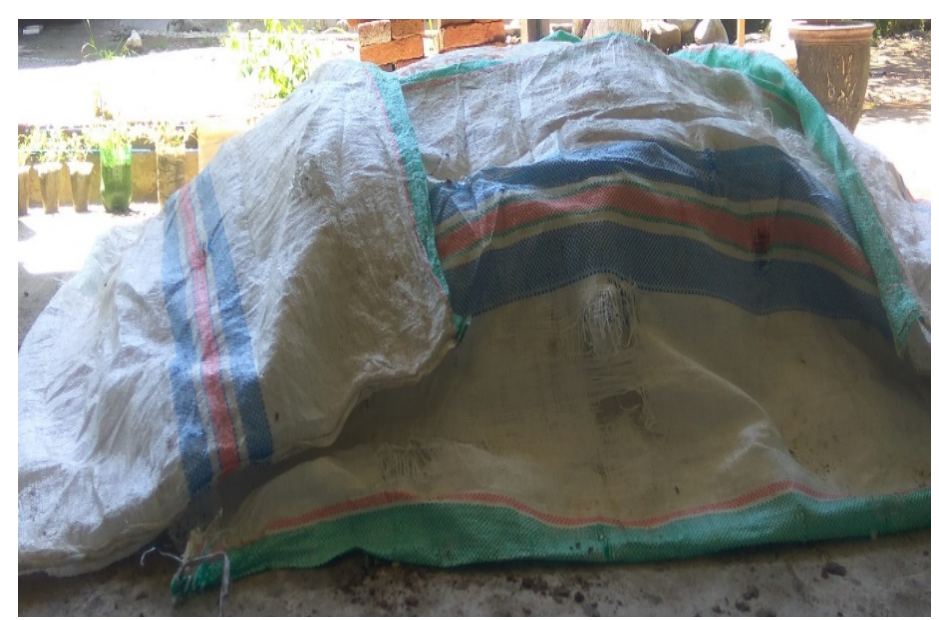

Gambar 5. Fermentasi bahan dasar kompos 
Proses ini memakan waktu 7 hari sampai kompos dinyatakan siap untuk diaplikasikan. Selama proses fermentasi berlangsung, dilakukan pengadukan secara berkala dan menjaga suhu campuran. Hasil akhir fermentasi menjadi kompos diperlihatkan pada Gambar 6. Berdasarkan Gambar 6, terlihat kompos memiliki sifat remah berwarna coklat kehitaman. Kelimpahan konsorsium mikroba dalam aktivator dan pengadukan secara berkala menjadi faktor yang mempengaruhi kecepatan kematangan kompos (Monica, et. al. 2016; Zhao, et. al. 2018; Mirdamadian, et. al. 2011; Djaja, 2008). Beberapa tindakan yang dilakukan untuk memanipulasi kematangan kompos agar lebih cepat yaitu dengan pertimbangan kandungan rasio $\mathrm{C} / \mathrm{N}$ bahan utama (dalam hal ini kotoran ternak), penjagaan suhu optimal $\left(30^{\circ}-70^{\circ} \mathrm{C}\right)$, aerasi bahan dan ukuran partikel bahan (Isroi dan Yuliarti, 2009).

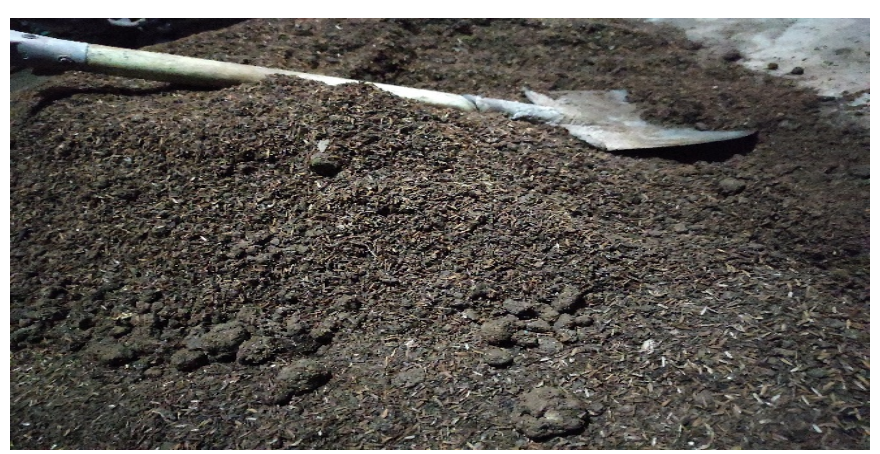

Gambar 6. Kompos hasil pelatihan

Tahapan kegiatan selanjutnya adalah aplikasi kompos yang telah dibuat. Gambar 7 merupakan pembuatan media tanam dari tanah dan kompos.

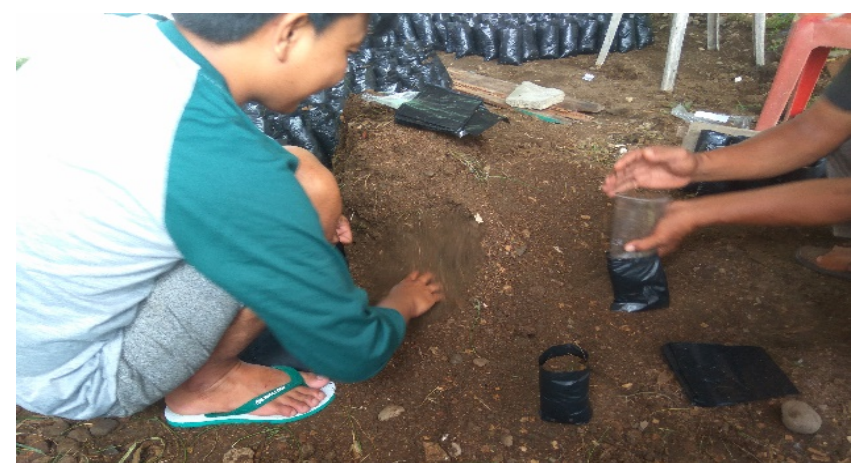

Gambar 7. Pembuatan media tanam jahe merah

Efektivitas kompos yang telah dibuat diperlihatkan pada Gambar 8.

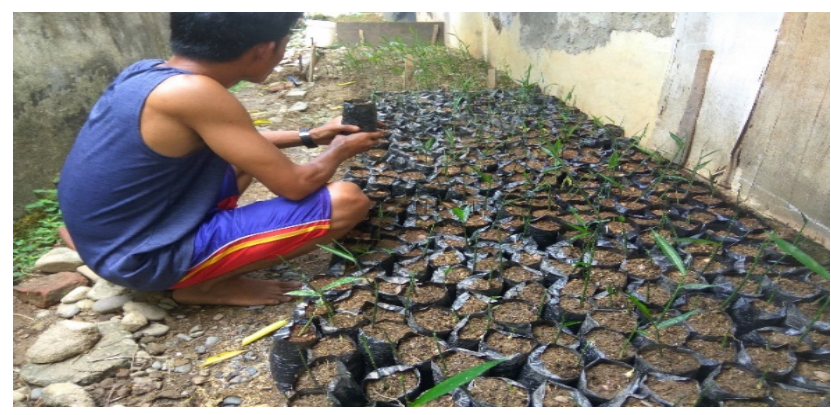

Gambar 8. Perkembangan pertumbuhan bibit jahe merah umur 3 pekan 


\section{Kesimpulan}

Pelaksanaan kegiatan ini memberi pilihan alternatif pupuk tanaman bagi masyarakat khususnya peserta kegiatan. Dengan memanipulasi faktor yang mempengaruhi pengomposan, waktu fermentasi kompos dapat dipersingkat secara efektif. Kegiatan lanjutan yang dapat dikembangkan dari kegiatan ini adalah merancang pembuatan pupuk organik cair.

\section{Ucapan Terimakasih}

Ucapan terima kasih diberikan kepada Universitas Cokroaminoto Palopo atas bantuan hibah hingga kegiatan ini terlaksana dengan lancar. Ucapan terima kasih juga diberikan kepada aparatur pemerintah dan warga Kel. Boting, Kec. Wara Kota Palopo yang mendukung keterlaksanaan kegiatan.

\section{Referensi}

Anonim. (2020). Red Ginger Increases Immunity, Prevents Coronavirus Infection. Indonesia Window. Retrieved from https://indonesiawindow.com/en/red-gingerincreases-immunity-prevents-coronavirus-infection/

Assegaf, S., Kawilarang, A. P., Handajani, R. (2020). Antibacterial Activity Test of Red Ginger Extract (Zingiber officinale var. rubrum) Against Streptococcus pyogenes in vitro. Biomolecular and Health Science Journal. 8(1). http://dx.doi.org/10.20473/bhsj.v3i1.19130

Costa, M. S. S. De M., Carneiro, L. J., Costa, L. A. De. M., Pereira, D. C., Lorin, H. E. F. (2016). Composting Time Reduction of Agro-Industrial Wastes. Journal of the Brazilian Association of Agricultural Engineering. 36(6). https://doi.org/10.1590/18094430-Eng.Agric.v36n6p1206-1217/2016

Djaja, W. (2008). Langkah Jitu Membuat Kompos dari Kotoran Ternak dan Sampah. Tangerang: PT AgroMedia Pustaka.

Isroi \& Yuliarti, N. (2009). Kompos: Cara Mudah, Murah dan Cepat Menghasilkan Kompos. Yogyakarta: ANDI OFFSET.

Mirdamadian, S. H., Khayam-Nekoui, S. M., Ghanavati, H. (2011). Reduce of Fermentation Time in Composting Process by Using a Special Microbial Consortium. World Academy of Science, Engineering and Technology 76 2011. Diakses dari https://www.researchgate.net/publication/247160288_Reduce_of_Fermentation _Time_in_Composting_Process_by_Using_a_Special_Microbial_Consortium

Mufti, R. R. (2020). People Rush for Red Ginger Supplements as COVID-19 Fears Grow. The Jakarta Post. Retrieved from https://www.thejakartapost.com/news/2020/03/12/people-rush-for-redginger-supplements-as-covid-19-fears-grow.html.

Supu, R. D., Diantini, A., Levita, J. (2018). Red Ginger (Zingiber officinale var. rubrum): Its Chemical Constituents, Pharmacological Activities and Safety. Fitofarmaka Jurnal Ilmiah Farmasi. 8(1): 25-31. 10.33751/if.v8i1.1168 
Zhao J, Liu J, Liang H, Huang J, Chen Z, Nie Y, et al. (2018) Manipulation of the rhizosphere microbial community through application of a new bio-organic fertilizer improves watermelon quality and health. PLoS ONE 13(2): e0192967. https://doi.org/10.1371/journal.pone.0192967 